\title{
FEAR TIME VERSUS SCIENCE TIME: DISCURSIVE DISPUTES OVER THE EPIDEMIC OF THE ZIKA VIRUS AND MICROCEPHALY IN BRAZIL
}

\author{
Simone Evangelista Cunha \& Marcelo Garcia
}

\begin{abstract}
This article discusses some of the tensions caused by the friction between distinct temporal regimes associated with an epidemic episode. This text is based on the study of the way information related to the Zika epidemic and microcephaly in Brazil was speeded out during the year 2015-2016. Starting with the context of intense mediatization, as well as of the complex temporality produced by digital communication technologies, we sought to analyze the relationship between human and non-human actors that contributed to the social construction of this epidemy. The focus of the text are the videos produced by the "lay" public who also spread rumors which show likely alternative explanations about the epidemy.
\end{abstract}

\section{O TEMPO DO MEDO VERSUS O TEMPO DA CIÊNCIA: DISPUTAS DISCURSIVAS SOBRE A EPIDEMIA DE VÍRUS ZIKA E MICROCEFALIA NO BRASIL}

\begin{abstract}
Resumo
O artigo propõe-se a discutir alguns dos tensionamentos desencadeados pelas fricções entre regimes temporais distintos envolvidos num episódio epidémico. $O$ texto tem como base $o$ estudo de caso sobre a difusão de informações relacionadas com a epidemia de Zika e microcefalia no Brasil no verão de 2015/2016. A partir do contexto de mediatização intensa e da complexa temporalidade produzidas pelas tecnologias digitais de comunicação, procuramos analisar a relação entre atores humanos e não-humanos que contribuíram para a construção social dessa epidemia em particular. Nosso foco recai, em especial, sobre a produção de vídeos pelo público "leigo" que disseminam boatos com possíveis explicações alternativas para a epidemia.
\end{abstract}

\section{PALAVRAS-ChAVE}

Mediatização; risco; tempo; vírus Zika; YouTube 


\section{INTRODUCTION}

According to the historian Charles Rosenberg (1992), spite its biological nature, every disease condenses a combination of social meanings. That is, it is a complex intellectual construction. In the same way, Janine Cardoso (2012) sustains that when diseases emerge, they mobilize cultural and cognitive repertoires which are embedded in the social organization. They also inscribe historically constructed relations of knowledge and power. The initial or critical phase of the Zika virus that plagued Brazil between October 2015 and February 2016 was marked by doubts, uncertainties, and fear. Many researchers and health professionals compared it with other epidemic situations in the country - especially AIDS, in the early eighties of the twenty century. Although biologically very different, both diseases share some similarities concerning the contexts in which they emerge: little was known about them. There were many scientific uncertainties about all the aspects associated to them. The two epidemics have gained enormous prominence in the press, and both meant (and still mean) serious public health problems.

Addressing the concept of social construction of AIDS, Norman Fairclough (2001) shows that it results in a process that combines various discourses (such as venereology, cultural "invasion" by "foreigners", and pollution). Establishing a parallel with the Zika virus, this disease also involved the proliferation of narratives that intertwined viruses, mosquitoes, conceptions about motherhood, abortion and vaccination, xenophobia, and politics. These discourses appear in the media, on webpages, and on social networks and they played a major role during the episode (Garcia, 2017). They proved themselves to be constitutive of the temporal discontinuity created by fear and risk that were dominating the passage of time.

The speed at which information about Zika and microcephaly circulates, and the interest aroused by the unknown disease were an opportunity to analyze the tensions emerging from the process of mediatization that takes place in contemporary society. According to Muniz Sodré (2007), mediatization gives account of the way traditional social institutions interconnected with the media. Also according to Fausto Neto (2008), mediatization redesigns interactional processes and suggests the production of a new environment, with the displacement of producers and receivers in the process of communication to a new contact zone, based on the logics of circulation and of non-linear temporality.

In other words, José Luiz Braga (2012) confirms that, in the mediatized society, all social fields, including (and perhaps especially) the scientific, appear to be more associated with the needs for "external" interaction, due to the potential conflict triggered by actors outside the field, or due to the possibility of interaction with the external environment outside the logics of the field. Such diffuse processes and logics, which are typically inscribed in the mediatization, show a scenario in which the refractive capacity, as well as the sphere of the legitimacy of the autonomous fields, get diminished, offering states of temporal discontinuity, as well as the emergence of varied and contradictory times.

In a context in which the internet is an increasingly important source of health information, citizens often pretend to be specialist (Vasconcellos-Silva \& Castiel, 2010; 
Garbin, Pereira Neto \& Guilam, 2008). They get immersed in a "kind of market of various versions of plausible truths - suddenly urgent - requiring us to make unequivocal decisions" (Vasconcellos-Silva \& Castiel, 2010, p. 4). In this article, we focus on the temporal nature of the discursive disputes about the Zika virus epidemic in Brazil. We address the tensions caused by the frictions between temporal regimes that characterize the network of human and non-human actors (Latour, 2000). This includes controversies over the episode, and the digital social networking platforms. When we analyze the epidemic as a panic event, uncertainty, and ignorance, we get absorbed in the process of social production of knowledge that happens a part from the scientific field itself. Bruno Latour (2000) calls this the black box'. In this case, a short interval of intense semantic production, by which Zika episode gains its most extraordinary contours.

In the first part of the article, we discuss the temporal disjunctions regarding scientific practice and discourses about science considering the high degree of reflexivity experienced in our society (Giddens, 1991). As a result of the accumulation of scientific knowledge, as well as of the changes over the course of modernity, this reflexive character raises a sequence of new questions, which are emblematic of our time regarding the role of science and its relation to the production of risk and uncertainty. Following, we establish a correlation between the strengthening of the "I-pistemology" rhetoric (Van Zoonen, 2012) and the spread of alternative narratives about the epidemy. Finally, we present a brief study following the content analysis of three videos published on YouTube by which rumors are dealt with as possible explanations for the problem.

This paper subscribes to Gary Kpreps's (2013) proposition about the relevance of studies on communication and health for the development of public sector policies. According to the author, it is fundamental to carefully examine the influence of communication on critical issues involving at-risk populations, health professionals, and other actors important to the modern healthcare system. In a scenario in which disinformation spreads easily and always by shorter periods of time through digital media, we argue that it is crucial to understand the narratives about the implementation of health promotion policies.

This is a reflexive text in which the epidemic of the Zika virus and microcephaly is taken as leitmotiv for problematize the field of communication and health in contemporary societies and the importance that time, and temporalities have on that.

\section{Population time Versus SCIENCE TIME}

Analyzing the perspectives of science at the turn of the century, Boaventura de Sousa Santos (1988) described the ambiguous situation in which a stunned humanity found itself. According to the author, we were (and, in our view, still are) at a crossroads of "shadows of a past that we either think we are no more, or think we did not stop to be,

\footnotetext{
'The expression, as Latour (2000) explains, is used in cybernetics to represent a machine or a set of complex commands, which is represented by a black box; one only needs to know what goes into the black box and what comes out of it, however contentious its history or however complex its operation. After stabilization, the social process of constructing the black box becomes invisible.
} 
and the shadows of a future in which we think we already are or will never be" (Santos, 1988 , p. 46). The sociologist asserts that if we look at the future, two contradictory images alternately come to our mind: that of our arrival at the threshold of a society freed from the shortcomings and insecurities of the technological translation of accumulated knowledge and that of the dangers that make us fear a future that will end before it begins.

One can align Santos's perception with Anthony Giddens's seminal analysis of the reflexive character of modernity. According to Giddens (1991), modernity is a doubleedged phenomenon: the development of modern institutions and their worldwide expansion have created opportunities for a safer and more comfortable existence, but they also carry a dark side because they intensify people's experience of uncertainty and fear (Giddens, 1991). From this viewpoint, the perils of modernity are not the fruits of immediate and certain direct cause-and-effect relationships; on the contrary, they are associated with potentials, that is, with possibilities difficult to determine. This is a situation which generates a global scenario of non-quantifiable uncertainties. Uldrich Beck (2010) also characterizes modern society by the uncertainties and threats produced and heightened by progress. In modern society, science assumes an extremely important role as a legitimizer of social knowledge and practice, but at the same time, it seems to be less and less enough for binding the definition of truth (Beck, 2010), contributing to the experience of risk, uncertainty, and temporal discontinuity.

Extreme and disparate situations such as natural disasters, decentralized cyberattacks, or public health epidemics exemplify the anguish and insecurities that arise from the ambiguities surrounding scientific practice. Luis David Castiel (1999) states that knowledge no longer has the bond it had with deterministic ideals; knowing no longer implies reaching unconditionally stable certainties. Although the results and promises of science are increasingly mirrored in each sphere of our daily life (Tucherman \& Ribeiro, 2012), science itself rests on quicksand in the society of risk (Giddens, 19991), producing discontinuous and fragmented times.

Following Igor Sacramento and Izamara Bastos Machado (2015) one can argue that this permanent temporality of risk is widespread in narratives about catastrophe, accidents, and epidemics, particularly in the area of journalism. Stories and experiences designed to stimulate identification between the reader/spectator and characters who suffer contribute to the perception that such unforeseen events can occur at any time, reflecting in a constant present the possibility of future. In a context in which scientific definitions about dangers are increasingly intertwined with social expectations and assessments (thus far from irrefutable truths), the mediatized experience of these events permeates all aspects of time in everyday life.

It should be remembered that, in contrast to a common view, time is performed and culturally constructed through the work of different instances. This way, media and communication processes influence our perception of time and affects our time regimes, further complicating the relationship between citizens and science. However, the relation between time and the media presupposes the interplays of different temporalities (West-Pavlov, 2012). These processes take different forms, stemming from the symbolic 
and social uses of the different media throughout history, in a way that "each communicational process engenders one or more regimes of temporality" (Musse, Vargas \& Nicolau, 2017, p. 8). Now, as Marialva Carlos Barbosa (2017) argues, time becomes even more recognized as tangible because of digital technologies. On different platforms, it is increasingly easy to revisit and reconstruct the past in the present, as well as bring forward and debate projections about the future. The relationship among temporalities and media is marked by a fluid and volatile time, "governed by the exponential logic of acceleration" (Barbosa, 2017, p. 20).

The acceleration of time points not to the teleological projection of a future, nor to the recovery of a past, but to a social experience based on instantaneity and temporal condensation (Matthew, 2013). This way, daily time is no longer cyclical nor linear, but pointillistic, marked by successive disintegrations (Maffesoli, 2003). As Zygmut Bauman (2007) argues, time's inconsistency, lack of cohesion, and proliferation of discontinuities disengage the temporal links that reunite events, liquefying time. Memory changes, becoming a rhizomatic memory, spread throughout the nodes of the network, waiting to be retrieved and sent back, producing new relations with knowledge and the use of this knowledge (Matthew, 2013).

In the perspective of Muniz Sodré (2007), advanced communication technologies and the speed of information circulation produce another temporality, "real time", in which the customary experience of time is deeply altered; since everyone is virtually connected, individuals can be reached without delay. In this temporality condensed into the present, the "eternal present" (Sodré, 2007, p. 19), information tends to be marked by the speed at which is being transmitted, by immediacy, unlimited space, and low cost. Events always precede the possibility of individual interpretation just as the social criticism via communication technologies precedes individual and collective interpretation. The philosopher argues that discourse rhetorically controls society as a whole "generally abstract in relation to concrete territory and real-historical time in the same way as the language system is abstract in relation to discourse" (Sodré, 2007, p. 20).

In a similar way, Marialva Barbosa emphasizes that, in producing a reality in which events are always capable of being updated at great speed, the confluence of digital media also contributes to form an "extended present" (Barbosa, 2017, p. 20). That is to say, and in dialogue with Francois Hartog (2013), that the regime of historicity is marked by presentism, and because of this, the future, anticipated as a threat, is persistently brought to the present, reducing the experience of insecurity and risk. The media thus persistently activate the present, a trend reflected by the uninterrupted flow of information circulating in the media: "it is uninterrupted time that emerges from the narratives, especially in the online environment, not allowing the necessary pause for reflection" (Barbosa, 2017, p. 21).

Situations such as the Zika virus epidemic in Brazil are illustrative for understanding the intersections between risk theories and temporalities mediated by forms of communication, especially digital media. Without claiming to account for the totality of the elements involved in this configuration, we emphasize the following points for reflection. 
It is, in the end, a question of understanding the implications involved in the different temporalities related to the production and dissemination of science, news, and, in the context of social media sites, personal discourse.

In the field of health, although science aims to explain all phenomena through scientific methods, its discourse competes with other diverse beliefs (Pereira, Martins, Barbosa, Silva \& Gomes, 2013). Myths, popular beliefs, fears, and other social experiences about the health and disease phenomenon trigger very ancient mechanisms of understanding reality. In other words, scientific data is not always the main point of reference that informs people's thinking or actions concerning health issues (Pereira et al., 2013). As Fairclough (2001) also points out, the medical science discourse competes with a number of "alternative", holistic discourses (such as acupuncture and homeopathy), and popular folk discourses, a trend that's growing due to the increasing ease of access to information, including technical and specialized, through Information and Communication Technologies (ICT).

Another central aspect of the present discussion is related to the temporality of scientific practice, different from the time of other social fields, such as the media, for example. If research, in principle, is characterized by a time of slow maturation, made of comings and goings, reconsiderations, evaluations and experiments, it distances itself from the aura of glamor that the very disclosure of scientific results in the media entails. Guided by the logic of spectacularization that organizes time and space for the articulation of "everyday events" that privilege the desire for consumption (Lefèbvre, 1991), the communication of science is influenced by a mystified vision of scientific activity. Priority is given to spectacular aspects, valuing immediate applications and suggesting, often, that something determined in the scientific field should not be debated. In this process, the media contribute to the construction of technoscientific fantasies that are an increasingly powerful part of our cultural landscape (Tucherman \& Ribeiro, 2012).

In the case of the Zika epidemic, it can be said that some of these relations were challenged, since the media could not initially find answers to the problem from researchers and scientific institutions. Even though the emergency situation has spurred the work of research institutes and prompted the organization of international conglomerates of scientists in search of solutions, as we will discuss in more detail below, it may take months (or years) of research to obtain enough knowledge to understand the situation. In this context, considering the speed at which information circulates on digital platforms of social networks and the public's eagerness for more immediate responses, multiple discourses came into conflict within the explanations given for the epidemic, with voices emerging from diverse fields such as politics, religion, entertainment, and journalism. This is well illustrated by the words of Ana Lúcia Azevedo, a former science editor of $O$ Globo newspaper mentioning about the period of the epidemic: "we had the feeling that we were constructing the knowledge together with the scientists" (OSM, 2016). 


\section{EVERYONE OWNS THE TRUTH}

In this context of many conflicting uncertainties and discourses in circulation, a phenomenon that Liesbet Van Zoonen (2012) classifies as "I-pistemologia" gains strength. In opposition to the concept of epistemology, related to the nature and methods of knowledge for uncovering truths, I-pistemology responds to individuals worries, stemming from the " $\mathrm{l}$ " and the identity, in detriment of institutions. Consequently, individuals "have transformed themselves into alternative sources of knowledge and understanding" (Van Zoonen, 2012, p. 63), in a search that favors new modes of expression. In this way, Van Zoonen, in dialogue with Jon Dovey (2000), asserts that subjective, autobiographical, and confessional discourses have been established forms of cultural expression since the 1990s. Dovey uses the term "first-person media" (Dovey, 2000) to speak about certain talk shows and the (then emerging) reality shows that reveal individuals' private lives and intimate experiences, unveiling their "real selves". This desire for "true authenticity", Van Zoonen (2012) says, includes content producers as well as companies, which must develop products and experiences that are always closer to reality. In the midst of this overabundance of the "real", it is up to each individual to determine, from their subjective perspective, what is authentic or not (Sibilia, 2008), based on its temporal instantaneity.

With the popularization of the internet, I-pistemology gains even more power, since the discourses about oneself gain unprecedented scope and variety. Through digital media, Van Zoonen (2012) points out, there is a plethora, not only of spaces in which subjects can express their own truths, but also of ways in which other individuals can establish correlations between their experiences and those to whom they access on the web. In some ways, sharing everyone's beliefs and experiences offers faster responses (and, according to the rhetoric of "I-pistemology" more reliable responses) to complex problems than science can provide. In this sense, it is worth remembering that technical characteristics of digital social networking platforms play a relevant role in articulating these constructions. In early 2018, Facebook, the most popular digital social network among Brazilians, announced that it would reduce the reach of news to prioritize posts from friends and family members in users' feed (Tozetto, 2018), for example.

This process of collective enunciation from the web of interactions between human and non-human actors (Latour, 1994) on digital platforms becomes even more evident in cases in which there are still few "official" responses, in which institutional time is delayed and provokes silences and periods of waiting, as was the case with the Zika virus epidemic. Further from the horizontality propagated by the idea of a collective intelligence (Lévy, 1999) than to disputes about meaning among diverse subjects, this process is based on the potential to produce narratives considered "authentic". Within this logic, besides the questioning of institutional discourses, individuals that don't have scientific backgrounds become relevant within certain networks associated with scientific contents on the internet (Oliveira et al, 2017). YouTube, the largest online video platform, has been a prolific channel for this type of manifestation, with its "star system" (Burgess \& Green, 2009) established by science-related content producers in Brazil. 
Considering the popular appeal of the theme and the already huge flux of searches about health contents on the internet, it is not surprising that several youtubers (regular content producers) had produced videos on Zika at the height of the epidemic. In addition to the youtubers' possible good intentions, it was an opportunity to build social capital on the internet. Recognition of a content producer as a reliable source of information about a problem worrying the population would increase his or her authority, that is, their influence on a specific network (Recuero, 2009). Given the lack of official information about Zika, rumors about likely "secret" information, which used to circulate exclusively in different social networking platforms (Garcia, 2017), also became prominent on YouTube. Numerous YouTubers produced content defending such alternative narratives, questioning them, or simply presenting them to their audiences.

Moreover, it is worth noting that in February 2018 a report by the American newspaper The Wall Street Journal pointed out it was possible that YouTube was being encouraging radical discourses (Nicas, 2018). Conducted with the participation of an ex Google staff member the investigation demonstrated that the platform frequently suggested far-right or far-left content to users who had previously viewed informative and relatively "neutral" content in an attempt to make these users spend more time on the site. In the healthcare field, the topic of vaccination was emphasized: according to the newspaper, when reading information on influenza vaccines, the public was encouraged to see contents about conspiracies of the anti-vaccination movement. The accusations were reiterated by another former employee of the company in a testimony made to the British newspaper The Guardian. According to him, the algorithm used in the platform for recommendations misrepresents reality and lead people to spend more time online (Lewis, 2018). It's an hot-headed context that spreads narratives of different nature, such as those analyzed throughout this work.

According to Jean-Bruno Renard (2007) and Jean-Noel Kapferer (1990), it is true that rumors are part of our daily lives and have been an important and immemorial sources of information since. This conceptualization is reinforced, for example, by Gordon Allport and Leo Postman (1973). These authors assert that much of our day-to-day communication is made of rumors. Zigmunt Bauman (2007) also makes important contributions to understand the process of producing and spreading rumors in the digital and temporally discontinuous contemporaneity. According the author, in "liquid times", the breaking down of boundaries, the deregulation, the weakening of human relations bring to mind "the terrifying experience of a heteronomous population, unhappy and vulnerable, confronted and possibly overpowered by forces it neither controls nor completely understands" (Bauman, 2007, p.13). According to the author, the insecurity of the present and the uncertainty of the future, are linked with the individual feeling of powerlessness.

From Eni Orlandi's (2005) viewpoint, rumor cannot be understood as hearsay, as fair-minded speech. It is an additional element in the dispute for the paradoxical territory of production of meaning. Gossip occurs in a time of its own, affecting the rhythm of what is said, expressed not only through words, but also silence, saying less (not saying the "whole", truth; fact is not "completely" meaning) or too much (it goes beyond truth). 
In this way, says Orlandi (2005), we can see the sides of what is said, the margin of misunderstandings, uncertainties. The author's conceptions complement the ideas of Kapferer (1990), Renard (2007), and Luiz Carlos Lasbeck (2000), who suggest that rumors arise when a group tries to ascribe meaning to uncertain and ambiguous circumstances. That is, when information is scarce and people suspect that perhaps much more may exist behind the "authorized" version, thereby pointing to other interpretative options.

These long-winded narratives, dislocated from a "place of origin", made of unstable, changeable elements, are conveyed informally, quintessentially, between ears generating connivance and settling bonds of trust (Lasbeck, 2000). The familiarity, the orality, and the conversational features of digital network communication (Fairclough, 2001; Recuero, 2012), favor the circulation of rumor while a transgressive phenomenon, that do not disappear with new technologies (Lasbeck, 2000; Reule, 2008). Instead, the rumor is strengthened by the temporal regimes of these spaces, which strengthen and are strengthened by the acceptance of the I-pistemology rhetoric.

In the next topic, we will examine the disputes of meaning around the Zika virus, highlighting the emergence of YouTubers while agents the disseminate alternative narratives about the disease which contribute to the emergence of a fragmented, and conflictive temporality during the period of "crisis".

\section{CASE STUdy: NARRATIVes AbOUT THe Zika virus in BraziL}

The Zika virus (ZIKV) appeared in Brazil without a stir. At first it was responsible for mild medical conditions. Then, it became one of the major national public health problems in recent years. The main factor that explains the population's fear, the health authorities' concern, and the great media interest in the disease is due to the effects on the rise of congenital malformations (especially microcephaly), in addition to other serious problems such as Guillain-Barré syndrome - an autoimmune neurological disease that normally causes infections.

Scientific reports about Brazil relate that the former virus manifestations occurred at the beginning of the year 2015. The disease was dealt with until October, when the alerts about the increased cases of microcephaly confirmed the suspicion that Zika was responsible for those diseases. Local newspapers made public this suspicion during the month of November (Aguiar \& Araújo, 2016). Facing 150 suspected cases of microcephaly, the Ministry of Health declared it a public health emergency on November 11 (Governo declara emergência em saúde por casos de microcefalia, 2015). During the same month, tests Oswaldo Cruz Foundation (Fiocruz) and the Evandro Chagas Institute confirmed the association between the Zika virus and the microcephaly (Ministério da Saúde confirma relação entre microcefalia e o vírus da Zika, 2015). The disease spread throughout Latin America and led the WHO to declare it a public health emergency of international concern on February $1^{2}$. This facilitated the mobilization of resources and the intensification of the scientific discussion. Soon, the, Zika began to lose ground in the news, partly

\footnotetext{
${ }^{2}$ Retrieved from http://www.who.int/mediacentre/news/statements/2016/emergency-committee-zika-microcephaly/en/
} 
because of the President Dilma Rousseff's impeachment process, and partly because of the Aedes aegypti (the mosquito yellow fever), that normally rises in cooler months.

At the height of the epidemic, it there was a need to recuperate the few existing historical records on Zika. Researchers tried to discover when it arrived in Brazil, examining about 30.000 accounts of outbreaks in French Polynesia between 2013 and 2014 (Jouannic, Friszer, Leparc-Goffart, Garel \& Eyrolle-Guignot, 2016). At the time, the outbreak was considered a "mild dengue" that subsided without severe aftereffects. After the start of the epidemic in Brazil, however, the analysis of current data showed a correlation between Zika infection during the first months of pregnancy and an increase in domestic cases of microcephaly.

The association between the virus and the microcephaly made the epidemy to become an important social event, reinforcing the feelings of unpredictability, insecurity, and uncertainty which are already part of the risk society (Antunes, Alves, Goveia, Oliveira \& Cardoso, 2016). The rumors amplified, and the same happened with the institutional and scientific efforts enacted to deal with the crisis.

The rules to apply to research funds were modified in order to faster the research about the disease. The São Paulo Research Foundation (FAPESP) approved extra resources to fund emergency projects about Zika in December 2015. Other agencies, such as the Coordination for the Improvement of Higher Education Personnel (CAPES) as well as the Ministry of Science and Technology also streamlined the appliance processes In March 2016 they announced a founding amount of around $\mathrm{R} \$ 1.2$ billion ${ }^{3}$ for public campaigns in several areas. WHO announced February 2016 a US\$56 million plan to battle Zika epidemy (OMS lança plano de US\$ 56 milhões para combater epidemia de Zika). The cooperation and collaboration among researchers was also intensified. Several collaborative initiatives were putted in practice. The ZIKAlliance research consortium, integrating partners from around the world and coordinated by the French National Institute of Health and Medical Research (Inserm) was one of the examples

Additionally, scientific community also asserted several initiatives to deal with the need to improve research. The scarcity of scientific information on the disease was the main difficulty to overpass. Therefore, the journals took decisions to speed up publication. Approximately one thousand articles about the disease were indexed in PubMed during the first months after the epidemicwell recognized journals in the field, such as Memórias do Instituto Oswaldo Cruz [Memories of the Institute Oswaldo Cruz], created special publishing workflows. The mission was to accelerate the peer review process ${ }^{4}$.

While the scientific community enrolled in that discussion, the population and the media also attempted to figure out what was happening In a temporal context marked

\footnotetext{
3 "Government will invest R\$649 million in coping with Zika and Aedes aegypti". Retrieved from http://www.brasil.gov.br/ noticias/saude/2016/03/enfrentamento-do-zika-e-do-aedes-vai-contar-com-r-649-mi-1

4 The results of all of these efforts were reflected in the groundbreaking identification of the relationship between Zika and microcephaly in Brazil, early in the epidemic. In January, Fiocruz announced the creation of a diagnostic kit for Zika, Chikungunya, and dengue to try to overcome the great difficulty of differentiation between the three diseases, with similar symptoms. But the accelerating efforts of science time are limiting: research for developing a vaccine still has a long way to go before bringing about effective results, even three years after the outbreak.
} 
by uncertainty, panic got intensified, as well as the sense of urgency. In this scenario and as digital media propelled increasing sense of haste, a range of alternative explanations begun to circulate giving explanations for the increase number of cases of microcephaly. Authorities labeled them as as rumors. The fact is that in reaction to the lengthy of the time needed to conduct studies and in-depth reflections on the numerous factors associated with the problem, simplistic responses several digital platforms begin to propagate simplistic responses Besides satisfying the population's quest for answers, theories about the application of expired rubella vaccines and tests with mosquitoes modified/ infected with Wolbachia bacteria played a role in amplifying suspicions about science, thereby ascertaining the need to search for other sources of ready to apply knowledge.

Rumors soon spread out through several digital platforms. In this text one analyses video narratives posted on YouTube. This is a world leader in the consumption of online videos, the platform was chosen for its prominence in Brazil. According to Google's 2017 survey, $95 \%$ of the nation's internet users visit the portal monthly, and $59 \%$ of them agree that it is better to use YouTube than watching news (Google \& REDS, 2017). Besides, youtubers built strong ties with their audiences, by the way of internet micro-celebrities (Marwick, 2015). Therefore, it is an important element in the spreading alternative narratives about Zika. To develop this research, we took into consideration the thousands of videos published about the subject on the platform. Then we proceeded by delimiting a qualitative and intentional sample by which the subjects are selected according to the criteria that "derive from problems with research, from the characteristics of the observed universe, and the conditions and methods of observation and analysis" (Fragoso, Recuero \& Amaral, 2011, p. 78).

The initial search was focused on videos with narratives classified as rumors, and with mentions to the Brazilian epidemy. We also consider those with a significant number of views. One also used a temporal clipping comprising key moments of the epidemic. Doing this we selected three videos, titled "A verdade sobre o Zika virus e a microcefalia!" [The truth about the Zika virus and microcephaly!], "O Zika Virus nada tem haver com os casos de Microcefalia - o governo está mentindo" [Zika virus has nothing to do with cases of microcephalia - the government is lying], and "A TRAMA DIABÓLICA DO ZIKA VÍRUS" [THE DIABOLIC PLOT OF THE ZIKA VIRUS]5. Two selected videos were published in early December 2015, shortly after the official confirmation that Zika was the cause for most of the cases of microcephaly; the third video was launched in February 2016 , days after the WHO has announced that the Zika epidemic was a public health emergency of international concern.

In the next section we are going to analyse the videos based on a content analysis. According to Klaus Krippendorf's (1990) this method is an important tool for understanding the frequency at which certain subjects are framed. Published on the channel

\footnotetext{
${ }^{5}$ The use of capital letters in the title of the video abides by the original publication and was maintained in this article to highlight the strategy of visibility used by its author. Although it is a relatively common practice on YouTube, the use of capital letters in texts can also be understood, in the context of digital communication practices, as a scream. In this sense, it reinforces the sense of urgency that its author wishes to transmit.
} 
Liberdade (Freedom) on December 5, 2015, the first video, "A verdade sobre o Zika virus e a microcefalia!" 6 uses a set of reports produced by the Globo network to quest the official discourse about Zika. The video begins with the announcement confirming the virus is the cause of the outbreak of microcephaly in the Northeast of the country, as it appears in the Jornal Nacional (National News - the Brazil's most watched news program). By inserting text and editing tricks, such as repeating the reporter's advice for a national mobilization against mosquito-borne dengue, the author inquiries into the legitimacy of that discovery. Although not appearing physically, the author inserts the words (and the panicky tone) in the video, using black and white uppercase letters on a black, spotted screen board (suggesting the idea of contamination). All this is used to inquiry why mosquitoes had not spread the Zika virus until 2015. After highlighting a reporter's statement saying that mosquitoes should be prevented from being born, the author returns to the lettering giving the announcement: "we will now see a report that Jornal Nacional showed on 11/01/2014, over a year ago; I saved that news report since that day, when the government released genetically modified dengue mosquitoes over several parts of Brazil".

Then another new report begins. This time about an initiative with transgenic mosquitoes in the city of Juazeiro do Norte. The video is interrupted by a new insertion on the screen, noting: "that's right, you heard it correctly. Mosquitoes genetically modified and paid with citizens money! We're paying to be infected! Rule of 3: they create the problem, introduce the problem, and now they bring the solution!". The apocalyptic tone of the message reaches its peak with the sentence terminating the video: "buckle up ladies and gentlemen! On our way to I.N.W.O. and population reduction!".

The use of news videos leads to a double bias: The Ministry of Health is questioned. Media is also accused of being complacent with that lies. Besides creating this double bias, the author points out that he saved the Globo TV 2014 video about transgenic mosquitoes, suggesting that he was able to predict that the experiment would have later consequences. In this way, he presents himself as a vigilant person who rationally utilizes the available information to predict the dangers that threaten the future. A perspective that he shares with his audience, in search of legitimacy.

The second video, titled "O Zika virus nada tem haver com os casos de microcefalia - o governo está mentindo"7 [sic] was published on the channel Instituto Teológico Gamaliel [Theological Institute Gamaliel] on December 9, 2015. With a narrative entirely center around a first-person speech, it spotlights a man identified as Pastor Flávio Nunes who looks directly at the camera in a recording apparently made with a mobile phone. Over the course of two minutes and 34 seconds, the author states that "he cannot verify the accuracy", but he found out that microcephaly could be related to batches of expired rubella vaccines. The pastor also says that "if this is true", the government should admit its mistakes and stop fooling people. He ends the video with an open question about the

\footnotetext{
${ }^{6}$ The video is available at https://www.youtube.com/watch? $v=T k L x h w 044 \mathrm{Ag}$

7 The video is available at https://www.youtube.com/watch?v=pGB7JOMeiıU
} 
large number of incidences of microcephaly in the Northeast, reinforcing the possible correlation with expired vaccines that had been distributed in the region.

Interestedly, the extensive description of the video begins with a more assertive tone, with phrases like "everything is a government lie; they are afraid to compensate all the families that have been affected", "social networks will break the story at any moment, and we need to be ready to fight for the rights of the families that were affected". Only at the end the author writes "if this is really true I just don't know anymore...". As in the previous video, the author does not use any official source, which justifies his warning about the impossibility of verifying the accuracy of the story. However, in the corner of the video and in the video description, the pastor's title stands out in a probable attempt to reinforce the author's position of authority - and, consequently, the possibility that the rumors are somewhat legitimate.

The third video, "A TRAMA DIABÓLICA DO ZIKA VÍRUS", also relies on religion as a central argument to legitimize the act of spreading alternative narratives about the epidemic. Published on the channel Jefferson Netto on February 4, the video is a mobile recording made by the author while driving "in the cold of the United States". In addition to informing the viewer that he is in another country, Netto introduces himself as a doctor - the video informs the viewer that the author is a "clinical psychoanalyst with a specialization in family and educational psychoanalysis, and a doctor of philosophy of religion". He also says that he decided to record the video as a matter of urgency, since he has a mission "concerning prophetic matters". As part of this heavenly mission, the man says that he watches what is going on around him and that he must tell people about things that are "moving very fast". He then explains that he heard an alarming interview on the American channel InfoWars (presented by far-right activist Alex Jones, whose content was suspended in August 2018 from YouTube, Apple, Facebook, Spotify, and Twitter) (Ximénez de Sandoval, 2018). The interviewee is presented as Dr. Francis Boyle, an alleged international law expert trained at Harvard University and considered "top in the United States". He had made claims about the relationship between the epidemic and the genetically modified mosquitoes.

The author of the video also contrasts the mediatic and governmental discourse with the "truth" revealed by that American person. "The Globo network is calling it the good mosquito, but Dr. Francis warns that the consequences can't be known". To reinforce the legitimacy of his source, he asks the public to research Francis Boyle's credentials on Google. This way he implicitly reinforces the idea that each person has responsibility to seek out information so they can evaluate the risks of believing or not in official speeches. As a Brazilian who had the opportunity to get in touch with sources abroad, Netto presents himself as someone willing to share his privilege: "it is probably the first time you are hearing this in Portuguese. (...) Do not trust what the Brazilian media and the Brazilian government is saying". On the other hand, if the American's résumé (though it doesn't contain anything at all related to scientific research on health) is enough to give him credibility, the argument that guarantees Netto's authority, once

\footnotetext{
${ }^{8}$ The video is available at https://www.youtube.com/watch?v=uV7FTt2Vtls
} 
again, is divine. He ends the video by repeating that Bible - more specifically the descriptions of the apocalypse - waste main factor that lead him to be worry about the question.

The three narratives analyzed present some common characteristics. All of them are based to some extent on the idea of I-pistemology: when facing the lack of consistent information, they rely on personal experiences ("predicting" issues related to the genetic manipulation of mosquitoes, retelling stories what someone "heard", using divine "enlightenment" that leads to truth). Besides stating that the Brazilian government lied about the epidemic, "traditional" media are frequently singled out as agents of "conspiracy". Meanwhile, social networking platforms are characterized as spaces in which narratives allegedly silenced by both institutions find space - as the author of the second video suggests, "social networks will break the story at any moment".

It's no coincidence that the videos are underpinned by the same presentism (Barbosa, 2017) characterizing the temporal regimes which are mediatized by digital platforms. The author of video 1 recuperates old videos to rebuild the present narrative, manipulating the past to add coherence to the explanation. Meanwhile, the anxiety about the future and the need to discuss the threats in the present are strongly evidenced. Terms such as "get ready", "at any moment" and "very fast" emphasize the urgency and the unpredictability associated with the disease. More than seeking a solution to the problem, the authors want to point out culprits - particularly the Brazilian government and the media - and stablish religion (videos 2 and 3) as an alternative source of trust before chaos. Thus, in this eternal present (Sodré, 2007) different temporalities are shuffled, especially the time of science and the time of social networks and of mediatized society. Although the experiment with modified mosquitoes is still too recent to provide results scientifically supported, its potentials and the unknown risk are anticipated and "presentified", liquefying the links between past and future events (Bauman, 2007). Retrieving specific fragments of the network rhizomatic memory as a jumping off point, the constructed narrative becomes rooted in the discourse of risk and of the mythical temporality inspired by biblical apocalypse.

\section{FinAL CONSIDERATIONS}

Considering Bernardo da Costa's (2014) reflection on Eduardo Viveiros de Castro (2011), we can observe that "imaginary" conceptions may get legitimacy, since they can establish their own support networks leading to actual effects. This was what happened with the rumors analyzed in this study about the distribution of an expired or spoiled rubella vaccine. Therefore, rumour is an important element in the process of social production of the meanings about a phenomenon that is technoscientific and sociotechnical(Cardoso, 2012; Rosenberg, 1992). Apart from the credibility that science and research institutions received from the citizens, other human and nonhuman actors participated (and participate) in the social construction of the epidemic(s), such as Whatsapp groups, YouTube channels, historical reports of past epidemics, biblical reports, personal memories about dengue and $A$. aegypti, discourses from anti-vaccine 
movements, among others. These lead other actors to act, thus generating actual effects and consequences.

Critical situations such as the Zika virus show the ambiguous feeling described by Santos (1998) about the relationship between society and science in the 21st century. In a context of accelerated mediatization and immediatism, information is produced, circulates, and is consumed without pauses for reflection (Barbosa, 2017; Sodré, 2007), creating a disintegrated experience of time (Bauman, 2007; Maffesoli, 2003). We have seen how easy it is to bring past miseries to the present and enrollee in projections about a future potentially impossible because pf microcephaly. As scientists are also providers of uncertainty, there is a wide space for risk-time and uncertainty-time to progress and feed several projection discourses. In other words, scientific reasoning is giving the way to myths, fears, beliefs, and personal experiences (Fairclough, 2001; Pereira et al, 2013) that, in turn, also augment the already existing dangers characterizing the accelerated and mediatized society.

The analysis of Zika virus temporalities shows in any case that science, being under great pressure, tried to accelerate the processes, to invent shortcuts in order to obtain swifter responses, however without leaving the behind the rigor inscribed in the typical nature of the scientific process. What happens in terrain is that the diseases spread far beyond its biological scope giving raise to multiple discourses that circulate in a faster pace than scientific process Therefore, the proliferating silences and uncertainties (Orlandi, 2005) become filled of rumors and speculation.

Not assuming the responsibility for the content being disseminated, YouTube is a pivotal non-human actor strengthening a time-network of discourses based mainly on the "I-pistemology" (Van Zoonen, 2012), strengthened by the rhetoric of experience (Sacramento \& Machado, 2015). Even if not having profs to support the rumors being cultivated, the authors of the videos justify their use their own past knowledge to support their queries about the "truth" of Zika virus which they consider to be omitted from the official discourses. Thereby, they ascribe to themselves the power to predict before someone else the threats (suddenly urgent) (as the youtuber who brags for having "stored" a video about transgenic mosquitoes). The also justify their worry as a reponse to a divine demand made on them to reveal the secreat "divine call" they received to reveal that "secret".

In spite of not intending to map the process of the social construction of knowledge about Zika, we sought to contribute to understand at least one side of this event, the tensions arising from the divergences between the time which is necessary for the production of scientific knowledge and the urgency for answers. In addition to the impact that this conflicts of temporality may cause on the episode one may highlight the risk of emerging of health-related conspiracy theories that, within a framework of absolute temporal instantaneity, may play an important role in strengthening extreme right networks, as Rebecca Lewis (2018) notes in a report about English-language youtubers. This is a finding to be further analyzed in future works.

Translation: Robert Kaiser 


\section{FUNDING}

This article was supported by the German Academic Exchange Service (DAAD), with funds from German Federal Ministry for Education and Research (BMBF) through the project "Literary Cultures of the Global South".

\section{REFERENCES}

Allport, G. \& Postman, L. (1973). Psicología del rumor. Buenos Aires: Psique.

Aguiar, R. \& Araújo I. S. (2016). A mídia em meio às 'emergências' do vírus Zika: questões para o campo da comunicação e saúde. RECIIS - Rev. Eletrônica Comun., Informação Inovação em Saúde, 10(1), 1-15. http://dx.doi.org/10.29397/reciis.v10i1.1088

Antunes, M. N., Alves, W., Goveia, F. G., Oliveira, A. E. \& Cardoso, J. M. (2016). Arquivos visuais relacionados ao vírus Zika: imagens no Instagram como parte da constituição de uma memória da epidemia. RECIIS - Rev. Eletrônica Comun., Inf. Inov. Saúde, 10(3), 1-15. http://dx.doi.org/10.29397/reciis.v10i3.1175

Bauman, Z. (2007). Tempos líquidos. Rio de Janeiro: Jorge Zahar Ed.

Barbosa, M. C. (2017). Tempo, tempo histórico e tempo midiático: interrelações. Em C. F. Musse, H. Vargas \& M. Nicolau (Eds.), Comunicação, mídias e temporalidades (pp. 19-36). Salvador: Edufba.

Beck, U. (2010). Sociedade de risco: rumo a uma outra modernidade. São Paulo: Ed. 34.

Bourdieu, P. (2003). Os usos sociais das ciências: por uma sociologia clínica do campo científico. São Paulo: Unesp.

Braga, J. L. (2012). Circuitos versus campos sociais. Em M. A. Mattos, J. Janotti \& N. Jacks (Eds.), Mediação e midiatização (pp. 31-52). Salvador: Edufba.

Burgess, J. \& Green, J. (2009). YouTube e a revolução digital: como o maior fenômeno da cultura participativa transformou a mídia e a sociedade. São Paulo: Aleph.

Cardoso, J. M. (2012). Entre vítimas e cidadãos: risco, sofrimento e política nas narrativas do Jornal Nacional sobre as epidemias de dengue (1986-2008). Doctoral thesis, Universidade Federal do Rio de Janeiro, Rio de Janeiro, Brasil. Retrieved from http://www.pos.eco.ufrj.br/site/teses_dissertacoes_interna.php?tease=2

Castiel, L. D. (1999). A medida do possível... saúde, risco e tecnobiociências. Rio de Janeiro: Editora Fiocruz.

Costa, B. E. G (2014). As controvérsias da ciência na Wikipédia em português: o caso do aquecimento global. Doctoral thesis, Universidade Federal do Rio de Janeiro, Rio de Janeiro, Brasil.

Dovey, J. (2000). Freakshow: first person media and factual television. London: Pluto Press.

Fairclough, N (2001). Discurso e mudança social. Brasília: UNB.

Fausto Neto, A. (2008). Fragmentos de uma analítica da midiatização. Matrizes, 1(2), 89-105. Retrieved from https://www.revistas.usp.br/matrizes/issue/view/3169

Fragoso, S., Recuero, R. \& Amaral, A. (2011). Métodos de pesquisa para internet. Porto Alegre: Sulina.

Garbin, H. B. R., Pereira Neto, A. F. \& Guilam, M. C. R. (2008). A internet, o paciente expert e a prática médica: uma análise bibliográfica. Interface, 12(26), 579-588. http://dx.doi.org/10.1590/ S1414-32832008000300010 
Garcia, M. P. (2017). Disseram por aí: deu Zika na rede! Boatos e produção de sentidos sobre a epidemia de Zika e microcefalia nas redes sociais. Masters dissertation, Instituto de Comunicação e Informação Científica e Tecnológica em Saúde, Rio de Janeiro, Brasil. Retrieved from https://www.arca.fiocruz.br/handle/ icict/23607

Giddens, A. (1991). As consequências da modernidade. São Paulo: Unesp.

Google \& REDS (2018). Pesquisa Google e Reds com consumidores brasileirosa online. Retrieved from https://www.thinkwithgoogle.com/intl/pt-br/youtubeinsights/2017/de-play-em-play/

Governo declara emergência em saúde por casos de microcefalia (2015, November 11). G1. Retrieved from http://g1.globo.com/bemestar/noticia/2015/11/ministerio-da-saude-investiga-casos-de-microcefalia-nonordeste.html

Hartog, F. (2013). Ordens do tempo, regimes de historicidade. In F. Hartog, Regimes de historicidade presentismo e experiências do tempo (pp. 305-327). São Paulo: Autêntica.

lasbeck, L. C. (2000) Os boatos - além e aquém da notícia. Lumina, 3(2), 11-26. Retrieved from www.ufjf.br/ facom/files/2013/03/R5-lasbeck-HP.pdf

Jouannic, J. M., Friszer, S., Leparc-Goffart, I., Garel, C. \& Eyrolle-Guignot, D. (2016). Zika virus infection in French Polynesia. The Lancet, 387(10023),1051-1052. https://doi.org/10.1016/So140-6736(16)00625-5

Kapferer, J.N. (1990). Boatos: o meio de comunicação mais velho do mundo. Mem Martins: Publicações Europa-América.

Kreps, G. L. (2013). Health communication inquiry and health outcomes. Comunicação e Sociedade [Special vol.], 11-22. http://dx.doi.org/10.17231/comsoc.23(2012).1351

Krippendorff, K. (1990). Metodología de análisis de contenido: teoría y práctica. Barcelona: Paidos Iberica.

Latour, B. (1994). Jamais fomos modernos. Rio de Janeiro: Editora 34.

Latour, B. (2000). Ciência em ação: como seguir cientistas e engenheiros sociedade afora. São Paulo: Editora Unesp.

Lefèbvre, H. (1991). A vida cotidiana no mundo moderno. São Paulo: Editora Ática.

Lévy, P. (1999). Cibercultura. São Paulo: Editora 34.

Lewis, P. (2018, February 2). Fiction is outperforming reality: how YouTube's algorithm distorts truth. The Gaurdian. Retrieved from https://www.theguardian.com/technology/2018/feb/O2/ how-youtubes-algorithm-distorts-truth

Lewis, R. (2018). Alternative influence: broadcasting the reactionary right on youtube. New York: New Data \& Society [ebook]. Retrieved from https://datasociety.net/output/alternative-influence

Maffesoli, M. (2003). O instante eterno: o retorno do trágico nas sociedades pós-modernas. São Paulo: Zouk.

Mateus, S. (2013). O presenteísmo: meditações atuais sobre comunicação e temporalidade. Revista Fronteiras, 15(3), 170-181. http://dx.doi.org/10.4013/fem.2013.153.03

Ministério da Saúde confirma relação entre microcefalia e o vírus da Zika (2015, November 28). G1. Retrieved from http://g1.globo.com/bemestar/noticia/2015/11/ministerio-da-saude-confirma-relacao-entremicrocefalia-e-virus-zika.html

Musse, C. F., Silva, H. V. \& Nicolau, M. A. (2017). Comunicação, mídias e temporalidades. Salvador: Edufba 
Nicas, J. (2018, February 7). How youtube drives people to the internet's darkest corners. The Wall Street Journal. Retrieved from https://www.wsj.com/articles/ how-youtube-drives-viewers-to-the-internets-darkest-corners-1518020478

Oliveira, T., Evangelista Cunha, S., Toth, J. \& Lira, R. (2017). A ciência no Youtube: redes de autoridade e diferentes linguagens da Comunicação Científica na era digital. In Atas do I Congresso TeleVisões. Retrieved from https://congressotelevisoes.com.br/2017-2

OMS lança plano de US\$ 56 milhões para combater epidemia de Zika (2016, February 17). Folha de S. Paulo. Retrieved from https://m.folha.uol.com.br/cotidiano/2016/02/1740273-oms-lanca-plano-de-us-56milhoes-para-combater-epidemia-de-zika.shtml

Orlandi, E. P. (2005). Boatos e silêncios: os trajetos dos sentidos, os percursos do dizer. Em E. P. Orlandi, Discurso e texto: formulação e circulação dos sentidos (pp. 127-140). Campinas: Editora Pontes.

OSM. (2016). Debate: epidemias, jornalismo e (in)visibilidades. Retrieved from https://www.youtube.com/ watch? $v=$ Gptbuz7qn-o

Pereira, B. F. B., Martins, M. A., Barbosa, T. L., Silva, C. S. O. \& Gomes L. M. (2013). Motivos que levaram as gestantes a não se vacinarem contra HıN1. Ciência Q Saúde Coletiva, 18(6), 1745-1752. http://dx.doi. org/10.1590/S1413-81232013000600025

Recuero, R. (2009). Redes sociais na internet. Porto Alegre: Sulina.

Recuero, R. (2012). A conversação em rede: comunicação mediada pelo computador e redes sociais na internet. Porto Alegre: Sulina.

Renard, J. B. (2007). Um gênero comunicacional: os boatos e as lendas urbanas. Revista Famecos, 14(32), 97104. http://dx.doi.org/10.15448/1980-3729.2007.32.3421

Reule, D. (2008). A dinâmica dos rumores na rede: a web como espaço de propagação de boatos virtuais. Masters dissertation, Universidade Federal do Rio Grande do Sul, Porto Alegre, Brasil. Retrieved from https:// lume.ufrgs.br/handle/10183/13796

Rosenberg, C. (1992). Explaining epidemics. In C. Rosenberg, Explaining epidemics and other studies in the history of Medicine (pp. 293-304). Cambridge: Cambridge University Press.

Sacramento, I. \& Machado, I. B. (2015). A imigração como risco para a saúde: uma análise das representações do imigrante africano na cobertura da Folha de S. Paulo sobre o ébola. Comunicação e Sociedade, 28, 25-47. http://dx.doi.org/10.17231/comsoc.28(2015).2269

Santos, B. S. (1998). Um discurso sobre as ciências na transição para uma ciência pós-moderna. Estudos Avançados, 2(2), 46-71. http://dx.doi.org/10.1590/S0103-40141988000200007

Sibilia, P. (2008). O show do eu: a intimidade como espetáculo. Rio de Janeiro: Nova Fronteira.

Sodré, M. (2007). Sobre a episteme comunicacional. Matrizes, 1(1), 15-26. Retrieved from https://www. redalyc.org/articulo.oa?id=143017362001

Tozetto, C. (2018, January 13). Facebook muda algoritmo e reduz alcance de notícias. O Estado de S. Paulo. Retrieved from https://link.estadao.com.br/noticias/ empresas, facebook-muda-algoritmo-e-reduz-alcance-de-noticias,70002149049

Tucherman, I. \& Ribeiro M. S. (2006). Ciência e mídia: negociações e tensões. ECO-PÓS, 9(1), 244-259. http://dx.doi.org/10.29146/eco-pos.vgi1.1072 
Van Zoonen, L. (2012). I-pistemology: Changing truth claims in popular and political culture. European Journal of Communication, 2(1), 56-67. https://doi.org/10.1177/0267323112438808

Vasconcellos-Silva, P. R. \& Castiel, L. D. (2010). A internet na história dos movimentos anti-vacinação. ComCiência, 121. Retrieved from http://comciencia.scielo.br/scielo. php?script=sci_arttext\&pid=S1519-76542010000700011\&lng

Verón, E. (1998). Interfaces - sobre la democracia audiovisual evolucionada. Em J. M. Ferry \& D. Wolton (Eds.), El nuevo espacio público (124-139). Barcelona: Gedisa.

Ximénez de Sandoval, P. (2018, August 15). Facebook, Apple, Google e Twitter vetam a extrema direita paranoica. É uma boa notícia? El País [Brasil]. Retirado de https://brasil.elpais.com/brasil/2018/08/14/ internacional/1534273395-497058.html

\section{BIOGRAPHICAL NOTES}

Simone Evangelista Cunha is a journalist for the Federal University of Rio de Janeiro (UFF). She received her Master and Doctor of Communication at the Post-Graduate Program in Communication at the Fluminense Federal University (UFF). She is a researcher at the Research Laboratory in Urban Cultures and Communication Technologies (LabCult/UFF) and the Laboratory of Experiences of Engagement and Transformations of Audiences (LEETA/UFF).

ORCID: https://orcid.org/oooo-0002-5457-5737

Email: simone.evangelistacunha@gmail.com

Address: R. Alexandre Moura, 8 - São Domingos, Niterói - RJ, Brazil

Marcelo Garcia is a journalist. He received his Master of Science from the PostGraduate Program in Information and Communication in Health at the Institute of Scientific and Technological Communication and Information in Health (ICICT/Fiocruz), and he is a researcher at the ZIKAlliance consortium.

ORCID: https://orcid.org/oooo-0001-6183-2343

Email: marcelo.garcia@icict.fiocruz.br

Address: Av. Brasil, 4365, Rio de Janeiro - Brazil - 21040900

* Submitted: 08/08/2018

* Accepted: 13/11/2018 